\title{
Pengaruh suplementasi $\beta$-carotene terhadap kadar glukosa darah dan kadar malondialdehida pada tikus sprague dawley yang diinduksi Streptozotocin
}

\author{
Elida Soviana ${ }^{1}$, Banundari Rachmawati ${ }^{2}$, Nyoman Suci $W^{2}$
}

\begin{abstract}
Background : Hyperglycemia on diabetes mellitus can cause increasing of free radicals production. Free radicals caused lipid peroxidation reaction by forming malondialdehyde (MDA). $\beta$-carotene has antioxidant activity may inhibit the formation of ROS.

Objective : To prove the effect of multilevel doses $\beta$-carotene $1 \mathrm{mg} / \mathrm{kg} \mathrm{BW,20} \mathrm{mg/kg} \mathrm{BW}$ and $20 \mathrm{mg} / \mathrm{kg}$ BW on alternate days within 30 days orally supplementation on blood glucose level and MDA level on Sprague Dawley male rats induced by streptozotocin (STZ).

Methods : Thirty rats were randomly divided into 5 groups: $X_{1}=$ Negative control/diabetic, $X_{2}(S T Z 40 \mathrm{mg} / \mathrm{kg} B W+B C 1$ $\mathrm{mg} / \mathrm{kg} \mathrm{BW}), X_{3}\left(S T Z 40 \mathrm{mg} / \mathrm{kg} \mathrm{BW}+\right.$ BC 10mg/kg BW), $X_{4}(S T Z 40 \mathrm{mg} / \mathrm{kg} \mathrm{BW}+$ BC $20 \mathrm{mg} / \mathrm{kg} \mathrm{BW}), X_{5}$ (technic control/non diabetic). $\beta$-Carotene supplementation was given by nasogastric tube on alternate days within thirty days. Blood glucose level was measured by GOD-PAP and MDA level by ELISA with TBARS methods. Data was analized using paired t-test, wilcoxon, one way anova and post hoc bonferroni.

Results : there was a significant difference of blood glucose level $(p=0,0001)$ and MDA level $(p=0,0001)$ after suplementation $\beta$-carotene on alternate days within 30 days orally. $\beta$-carotene $10 \mathrm{mg} / \mathrm{kg} B W$ was the most effective and efficient dose to lowering blood glucose, while $20 \mathrm{mg} / \mathrm{kg} B W$ to lowering MDA level.

Conclusion: The multilevel doses $\beta$-carotene $(1 \mathrm{mg} / \mathrm{kg} \mathrm{BW,10} \mathrm{mg} / \mathrm{kg} \mathrm{BW}$ and $20 \mathrm{mg} / \mathrm{kg} \mathrm{BW}$ ) on alternate days within 30 days orally supplementation can decrease blood glucose and $M D A$ level. $\beta$-carotene $10 \mathrm{mg} / \mathrm{kg} \mathrm{BW}$ is the most effecetive and efficient to decrease blood glucose and $\beta$-carotene $20 \mathrm{mg} / \mathrm{kg} \mathrm{BW}$ to decrease MDA level.
\end{abstract}

Keywords : $\beta$-carotene, blood glucose level, MDA level, diabetes mellitus

\begin{abstract}
ABSTRAK
Latar belakang : Hiperglikemia pada diabetes mellitus dapat menyebabkan peningkatan produksi radikal bebas. Radikal bebas menyebabkan terjadinya lipid peroksida dengan membentuk malondialdehida (MDA). $\beta$-carotene memiliki aktivitas antioksidan yang dapat menghambat terbentuknya ROS

Tujuan : Membuktikan pengaruh dosis bertingkat $\beta$-carotene $1 \mathrm{mg} / \mathrm{kg} \mathrm{BB,} 10 \mathrm{mg} / \mathrm{kg}$ BB dan $20 \mathrm{mg} / \mathrm{kg}$ BB melalui sonde 2 hari sekali dalam 30 hari terhadap penurunan kadar glukosa darah dan kadar MDA pada tikus jantan Sprague Dawley yang diinduksi STZ.

Metode Penelitian: Tiga puluh tikus dibagi acak menjadi 5 kelompok =X1 (kontrol negatif/diabetik); X2 (STZ 40 mg/kg BB + $B C 1 \mathrm{mg} / \mathrm{kg} \mathrm{BB}) ; X 3(S T Z 40 \mathrm{mg} / \mathrm{kg} \mathrm{BB}$

+ BC 10mg/kg BB); X4 (STZ $40 \mathrm{mg} / \mathrm{kg}$ BB + BC $20 \mathrm{mg} / \mathrm{kg} \mathrm{BB);X5} \mathrm{(kontrol} \mathrm{teknik/non} \mathrm{diabetik).} \mathrm{Pemberian} \mathrm{BC} \mathrm{diberikan}$ melalui sonde, dua hari sekali dalam 30 hari. Kadar glukosa darah diperiksa menggunakan metode GDO-PAP, kadar MDA menggunakan ELISA dengan metode TBARS. Analisis data diuji dengan menggunakan paired t-test, wilcoxon, one way anova dan post hoc bonferroni.

Hasil : Ada perbedaan yang bermakna pada kadar glukosa darah $(p=0,0001)$ dan MDA $(p=0,0001)$ setelah diberi perlakuan $\beta$-carotene dosis bertingkat $1 \mathrm{mg} / \mathrm{kg} \mathrm{BB,} 10 \mathrm{mg} / \mathrm{kg} \mathrm{BB}$ dan $20 \mathrm{mg} / \mathrm{kg} \mathrm{BB}$ melalui sonde 2 hari sekali dalam 30 hari. Pemberian dosis $10 \mathrm{mg} / \mathrm{kg}$ BB merupakan dosis yang paling efektif dan efisien untuk menurunkan kadar glukosa darah dan dosis 20 untuk menurunkan kadar MDA.

Simpulan : Pemberian $\beta$-carotene dosis bertingkat $1 \mathrm{mg} / \mathrm{kg} \mathrm{BB}, 10 \mathrm{mg} / \mathrm{kg} \mathrm{BB}$ dan $20 \mathrm{mg} / \mathrm{kg} \mathrm{BB}$ melalui sonde 2 hari selama 30 hari dapat menurunkan kadar glukosa darah dan MDA. Pemberian $\beta$-carotene $10 \mathrm{mg} / \mathrm{kg}$ BB yang paling efektif dan efisien untuk menurunkan kadar glukosa darah dan $\beta$-carotene $20 \mathrm{mg} / \mathrm{kg}$ BB untuk menurunkan kadar MDA.
\end{abstract}

Kata Kunci : $\beta$-carotene, glukosa darah, malondialdehida, diabetes mellitus

\section{PENDAHULUAN}

World Health Organization memprediksi kenaikan prevalensi diabetes mellitus di Indonesia tiga kali lipat

\footnotetext{
${ }_{1}$ Program Studi Ilmu Gizi, Fakultas Ilmu Kesehatan, Universitas Muhammadiyah Surakarta, Indonesia

${ }^{2}$ Bagian Patologi Klinik Fakultas Kedokteran, Universitas Diponegoro, Indonesia
}

dari 8,4 juta pada tahun 2000 menjadi 21,3 juta pada tahun 2030. ${ }^{1}$ Hiperglikemia terjadi karena gangguan produksi, sekresi insulin atau resistensi insulin. Hiperglikemia pada diabetes mellitus dapat menyebabkan peningkatan produksi radikal bebas dan perkembangan dari stres oksidatif. Radikal bebas merupakan hasil dan produk normal metabolisme sel, namun pada beberapa keadaan dapat menimbulkan 
gangguan keseimbangan antara produksi ROS dan mekanisme perubahan seluler yang mengakibatkan disfungsi sel dan kerusakan sel. Radikal bebas menyebabkan terjadinya reaksi lipid peroksida dengan membentuk malondialdehida (MDA) dan kadar MDA yang tinggi dapat digunakan untuk penanda kerusakan oksidatif. Keterlibatan radikal bebas dalam menginduksi proses lipid peroksida pada membran sel akan menginisiasi terjadinya berbagai penyakit degeneratif. ${ }^{2}$

Antioksidan merupakan senyawa yang dapat menghambat ROS dan juga radikal bebas sehingga antioksidan dapat mencegah penyakit-penyakit yang dihubungkan dengan radikal bebas seperti kanker, aterosklerosis dan diabetes mellitus. $\beta$-carotene merupakan antioksidan yang mempunyai peran sebagai hipoglikemik terjadi melalui mekanisme penghambatan radikal bebas dan dapat menekan lipid peroksida didalam jaringan sehingga dapat mengurangi terjadinya komplikasi pada diabetes mellitus. ${ }^{3}$

Perubahan dosis $\beta$-carotene dapat memberikan efek yang berbeda terhadap penurunan stres oksidatif. Hal ini sesuai dengan penelitian Azza, membuktikan bahwa dengan pemberian dosis $\beta$-carotene $0,1 \mathrm{mg}$ dan $0,3 \mathrm{mg}$ pada hewan coba secara intraperitonial, dapat diketahui bahwa dengan pemberian dosis $0,3 \mathrm{mg}$ merupakan dosis optimum yang berpengaruh secara signifikan dapat menurunkan stres oksidatif dan sebagai efek protektif terhadap jaringan pankreas. Furusho et al membuktikan bahwa dengan pemberian dosis $\beta$-carotene $1 \mathrm{mg} / \mathrm{kg} \mathrm{BB}$ secara sonde dapat menekan lipid peroksida. Penelitian Sharma, et al menyatakan bahwa pemberian $\beta$-carotene $10 \mathrm{mg} / \mathrm{kg}$ BB pada tikus diabetik secara sonde dapat meningkatkan status antioksidan dan mengurangi stres oksidatif. Selain itu, penelitian yang dilakukan Thyagaraju, et al menyatakan bahwa dengan pemberian suplementasi $\beta$-carotene dengan dosis 20 $\mathrm{mg} / \mathrm{kg}$ BB tikus diabetik secara sonde dengan pemberian 2 hari sekali selama 4 minggu dapat meningkatkan kadar enzim antioksidan dan mengurangi ROS levels, sehingga $\beta$-carotene dapat digunakan sebagai pencegahan terhadap komplikasi pada diabetes mellitus.

Berdasarkan latar belakang tersebut maka peneliti akan meneliti pengaruh dosis bertingkat $\beta$-carotene yaitu dengan dosis $1 \mathrm{mg} / \mathrm{kg} \mathrm{BB}, 10 \mathrm{mg} / \mathrm{kg}$ BB dan 20 $\mathrm{mg} / \mathrm{kg}$ BB pada tikus jantan Sprague Dawley yang diinduksi streptozotocin $40 \mathrm{mg} / \mathrm{kg}$ BB dapat merubah kadar glukosa darah dan kadar MDA.

\section{METODE DAN BAHAN}

Penelitian ini merupakan penelitian eksperimental dengan rancangan randomized pre and post test controlled group design. Tikus (Rattus norvegicus galur sprague dawley yang dibagi dalam 5 kelompok yaitu kelompok $\mathrm{X}_{1}=$ kontrol negatif / diabetik (kelompok yang diinduksi STZ), kelompok $\mathrm{X}_{2}=$ perlakuan 1 (kelompok yang diinduksi STZ $40 \mathrm{mg} / \mathrm{kg}$ $\mathrm{BB}$ dan diberi $\beta$-carotene $1 \mathrm{mg} / \mathrm{kg} \mathrm{BB}$ ), kelompok $\mathrm{X}_{3}$ $=$ perlakuan 2 (kelompok yang diinduksi STZ 40 $\mathrm{mg} / \mathrm{kg} \mathrm{BB}$ dan diberi $\beta$-carotene $10 \mathrm{mg} / \mathrm{kg} \mathrm{BB}$ ), kelompok $\mathrm{X}_{4}=$ perlakuan 3 (kelompok yang diinduksi STZ $40 \mathrm{mg} / \mathrm{kg}$ BB dan diberi $\beta$-carotene $20 \mathrm{mg} / \mathrm{kg}$ $\mathrm{BB})$, kelompok $\mathrm{X}_{5}=$ kontrol teknik / non diabetik (kelompok yang tidak diinduksi STZ ).

Empat kelompok yang diinduksi STZ yakni kelompok $\mathrm{X}_{1}, \quad \mathrm{X}_{2}, \quad \mathrm{X}_{3}$ dan $\mathrm{X}_{4}$ dilakukan kadar pengukuran kadar glukosa darah setelah 18 hari.

Tikus dinyatakan diabetes apabila kadar kadar glukosa darah $>200 \mathrm{mg} / \mathrm{dl}$. Setiap kelompok dilakukan pre test dan post test untuk kadar glukosa darah dan MDA. Pemberian dosis bertingkat $\beta$-carotene diberikan secara sonde, 2 hari sekali dalam 30 hari. Kadar glukosa darah diperiksa dengan metode enzymatic colorimetric test GOD-PAP dan kadar MDA diperiksa dengan menggunakan ELISA.

\section{HASIL}

\section{Kadar Glukosa Darah}

Tikus jantan Sprague Dawley pada kelompok $\mathrm{X}_{1}$, $\mathrm{X}_{2}, \mathrm{X}_{3}$ dan $\mathrm{X}_{4}$ mendapatkan induksi STZ $40 \mathrm{mg} / \mathrm{kg}$ BB menunjukkan peningkatan kadar glukosa darah (Tabel 1).

Berdasarkan Tabel 1 dapat dilihat bahwa kelompok tikus yang mendapatkan induksi STZ $40 \mathrm{mg} / \mathrm{kg}$ BB yaitu kelompok $\mathrm{X}_{1}, \mathrm{X}_{2}, \mathrm{X}_{3}$ dan $\mathrm{X}_{4}$ selama 18 hari terjadi peningkatan kadar glukosa darah antara 348,80 $\mathrm{mg} / \mathrm{dl}$ sampai 382,10 mg/dl sehingga dapat dikatakan tikus jantan Sprague Dawley tersebut telah mengalami hiperglikemia.

Perlakuan dengan memberikan dosis bertingkat $\beta$ carotene (kelompok $\mathrm{X}_{2}, \mathrm{X}_{3}$ dan $\mathrm{X}_{4}$ ) dapat menurunkan kadar glukosa darah, masing-masing adalah 166,2 $\mathrm{mg} / \mathrm{dl}, 206,98 \mathrm{mg} / \mathrm{dl}$ dan $261,25 \mathrm{mg} / \mathrm{dl}$. Perlakuan $\mathrm{X}_{4}$ (pemberian $\beta$-carotene $20 \mathrm{mg} / \mathrm{kg} \mathrm{BB}$ ) menunjukkan penurunan kadar glukosa darah yang paling besar yaitu $261,25 \mathrm{mg} / \mathrm{dl}$.

Berdasarkan Tabel 1 dapat dilihat bahwa nilai $\mathrm{p}$ dari uji statistik paired t-test untuk kelompok perlakuan $\left(\mathrm{X}_{2}, \mathrm{X}_{3}\right.$ dan $\left.\mathrm{X}_{4}\right)$ yaitu 0,$006 ; 0,0001$ dan $0,0001(\mathrm{p}<0.05)$. Nilai $\mathrm{p}<0.05$ menunjukkan bahwa ada perbedaan rerata kadar glukosa darah yang bermakna antara sebelum dan setelah perlakuan. Kelompok perlakuan $\left(\mathrm{X}_{2}, \mathrm{X}_{3}\right.$ dan $\left.\mathrm{X}_{4}\right)$ setelah diberi $\beta$-carotene melalui sonde 2 hari sekali dalam 30 hari dapat menurunkan kadar glukosa darah. Kelompok kontrol negatif dan kontrol teknik memiliki nilai $\mathrm{p}$ 0,750 dan $0,184(\mathrm{p}>0,05)$. 
Tabel 1. Kadar glukosa darah tikus Sprague Dawley awal (sebelum induksi, pre test dan post test

\begin{tabular}{lccccc}
\hline \multirow{2}{*}{$\begin{array}{l}\text { Glukosa } \\
(\mathrm{mg} / \mathrm{dl})\end{array}$} & Darah & \multicolumn{5}{c}{ Kelompok } \\
\cline { 2 - 6 } & $\mathrm{X}_{1}$ & $\mathrm{X}_{2}$ & $\mathrm{X}_{3}$ & $\mathrm{X}_{4}$ & $\mathrm{X}_{5}$ \\
\hline awal $^{\mathrm{a}}$ Mean \pm SD & $75,44 \pm 11,74$ & $84,18 \pm 8,16$ & $79,88 \pm 4,54$ & $90,64 \pm 5,99$ & $88,96 \pm 11,64$ \\
pre test $^{\mathrm{b}}$ Mean \pm SD & $457,54 \pm 82,92$ & $432,90 \pm 70,16$ & $424,88 \pm 24,09$ & $498.38 \pm 23,63$ & $93,84 \pm 4,11$ \\
post test $^{\mathrm{c}}$ Mean $\pm \mathrm{SD}$ & $452,18 \pm 67,78$ & $266,72 \pm 70,14$ & $217,90 \pm 46,21$ & $237,15 \pm 19,59$ & $88,98 \pm 6,38$ \\
Delta 1 & 382,10 & 348,80 & 342,91 & 378,70 & 4,88 \\
Delta 2 & $-5,36$ & $-166,20$ & $-206,98$ & $-261,25$ & $-4,86$ \\
Nilai p & 0,750 & $0,006^{*}$ & $0,0001^{*}$ & $0,0001^{*}$ & 0,184 \\
\hline
\end{tabular}

a) Glukosa darah awal adalah glukosa darah pada saat memilih hewan coba untuk kriteria inklusi.

b) Pre test adalah glukosa darah tikus setelah diinduksi STZ dan telah terjadi hiperglikemia.

c) Post test adalah glukosa darah tikus setelah diinduksi STZ dan hiperglikemia serta mendapatkan suplementasi $\beta$-carotene selama 30 hari.

$\mathrm{P}($ value $)=$ paired-test

*= nilai p paired t-test, sangat bermakna

Nilai $\mathrm{p}>0,05$ menunjukkan bahwa tidak ada perbedaan rerata kadar glukosa darah yang bermakna antara pre test dan post test.

Hasil uji statistik one-way anova menunjukkan bahwa perubahan kadar glukosa darah setelah mendapatkan perlakuan $\beta$-carotene terdapat perbedaan yang signifikan $(\mathrm{p}=0,0001)$, artinya bahwa pemberian $\beta$-carotene dosis bertingkat (1 $\mathrm{mg} / \mathrm{kg} \mathrm{BB}, 10 \mathrm{mg} / \mathrm{kg}$ BB dan $20 \mathrm{mg} / \mathrm{kg} \mathrm{BB}$ ) dapat menurunkan kadar glukosa darah ditiap kelompok perlakuan. Selanjutnya diuji dengan menggunakan uji post hoc bonferroni didapatkan kesimpulan bahwa dosis $10 \mathrm{mg} / \mathrm{kg}$ BB merupakan dosis yang paling efektif dan efisien untuk menurunkan kadar glukosa darah.

\section{Kadar Malondialdehida}

Berdasarkan Tabel 2 menunjukkan bahwa kadar MDA pre test pada kelompok yang diinduksi STZ $\left(\mathrm{X}_{1}, \mathrm{X}_{2}, \mathrm{X}_{3}\right.$ dan $\left.\mathrm{X}_{4}\right)$ yaitu pada saat tikus jantan Sprague Dawley telah mengalami hiperglikemia dan sebelum perlakuan berkisar antara $5,10 \mathrm{nmol} / \mathrm{ml}$ sampai $5,42 \mathrm{nmol} / \mathrm{ml}$ dibandingkan dengan kelompok teknik yaitu $2,65 \mathrm{nmol} / \mathrm{ml}$.

Berdasarkan Tabel 2 dapat dilihat bahwa pada kelompok perlakuan $\mathrm{X}_{2}, \mathrm{X}_{3}$ dan $\mathrm{X}_{4}$ terjadi penurunan kadar MDA sebesar $0,75 \mathrm{nmol} / \mathrm{ml}, 0,85 \mathrm{nmol} / \mathrm{ml}$ dan $1,58 \mathrm{nmol} / \mathrm{ml}$. Penurunan kadar MDA paling banyak terdapat pada kelompok perlakuan yang diberi $\beta$ carotene dengan dosis $20 \mathrm{mg} / \mathrm{kg} \mathrm{BB}$.

Berdasarkan hasil uji statistik paired t-test dan uji wilcoxon bahwa kelompok perlakuan $\mathrm{X}_{2}, \mathrm{X}_{3}, \mathrm{X}_{4}$ diperoleh nilai significancy yaitu 0,$009 ; 0,028$ dan $0,003$ ( $\mathrm{p}<0,05)$. Dengan demikian dapat disimpulkan bahwa ada perbedaan antara kadar MDA sebelum dan setelah pemberian $\beta$-carotene

$1 \mathrm{mg} / \mathrm{kg} \mathrm{BB}, 10 \mathrm{mg} / \mathrm{kg}$ BB dan $20 \mathrm{mg} / \mathrm{kg}$ BB. Kelompok kontrol negatif dan kontrol teknik adalah
0,133 dan 0,16 , dengan demikian dapat disimpulkan bahwa tidak ada perbedaan kadar MDA sebelum dan setelah.

Hasil uji statistik one-way anova menunjukkan bahwa perubahan kadar MDA setelah mendapat perlakuan terdapat perbedaan yang signifikan $(\mathrm{p}=$ $0,0001)$, artinya bahwa pemberian $\beta$-carotene dosis bertingkat $(1 \mathrm{mg} / \mathrm{kg} \mathrm{BB}, 10 \mathrm{mg} / \mathrm{kg}$ BB dan $20 \mathrm{mg} / \mathrm{kg}$ BB) dapat menurunkan kadar MDA pada setiap kelmpok. Selanjutnya diuji dengan menggunakan uji post hoc bonferroni dapat disimpulkan bahwa pemberian dosis $20 \mathrm{mg} / \mathrm{kg}$ BB merupakan dosis yang paling efektif dan efisien untuk menurunkan kadar MDA.

\section{PEMBAHASAN}

\section{Kadar Glukosa Darah}

Kadar glukosa darah pada tikus yang diinduksi STZ mengalami kenaikan setelah 18 hari. Streptozotocin tersebut menyebabkan kerusakan sel $\beta$ melalui alkilasi DNA sehingga DNA menjadi rusak karena aktivasi dari poli ADP-ribosilasi dan proses tersebut akan memicu deplesi NAD+ selular dan menurunkan kandungan ATP. Dampak dari kondisi ini adalah terjadi penghambatan pada sintesis dan sekresi insulin, sehingga meningkatkan kadar glukosa darah. ${ }^{8}$

Matthew menyatakan bahwa hiperglikemia kronis merupakan katalisator utama untuk berbagai komplikasi mikrovaskuler pada penyakit diabetes seperti retinopati, neuropati dan nephropati. Kadar glukosa darah yang tinggi tersebut akan meningkatkan stres oksidatif melalui proses enzimatis maupun non enzimatis. Pada proses enzimatis akan terjadi perubahan fungsi protein misalnya NADPH oksidase sehingga menganggu dan merusak fungsi sel serta 
Tabel 2. Rerata kadar MDA dan perubahannya

\begin{tabular}{lccccc}
\hline \multicolumn{1}{c}{ Kelompok } & $\mathrm{X}_{1}$ & $\mathrm{X}_{2}$ & $\mathrm{X}_{3}$ & $\mathrm{X}_{4}$ & $\mathrm{X}_{5}$ \\
\hline pre test $(\mathrm{nmol} / \mathrm{ml})^{\mathrm{a}}$ Mean $\pm \mathrm{SD}$ & $5,4 \pm 0,26$ & $5,42 \pm 0,28$ & $5,23 \pm 0,36$ & $5,10 \pm 0,13$ & $2,65 \pm 0,14$ \\
post test $(\mathrm{nmol} / \mathrm{ml})^{\mathrm{b}}$ Mean $\pm \mathrm{SD}$ & $5,63 \pm 0,09$ & $4,67 \pm 0,12$ & $4,38 \pm 0,61$ & $3,52 \pm 0,69$ & $2,69 \pm 0,12$ \\
Delta MDA $(\mathrm{nmol} / \mathrm{ml})$ & 0,24 & $-0,75$ & $-0,85$ & $-1,58$ & 0,03 \\
Nilai p & 0,133 & $0.009^{*}$ & $0,028^{* \mathrm{c}}$ & $0,003^{*}$ & 0,16 \\
\hline
\end{tabular}

Keterangan:

a) Pre test adalah kadar MDA diinduksi STZ telah terjadi hiperglikemia dan sebelum perlakuan.

b) Post test adalah kadar MDA setelah diinduksi STZ dan hiperglikemia serta mendapatkan suplementasi $\beta$-carotene selama 30 hari.

c) Uji wilcoxon

$\mathrm{P}($ value $)=$ paired $t$-test dan wilcoxon

*= sangat bermakna

menimbulkan reactive oxygen intermediates yang dapat mengoksidasi LDL, sedangkan proses non enzimatis akan mengubah ekspresi gen (growth factor dan cytokine) serta menganggu pertahanan antioksidan (meningkatkan stres oksidatif) yang berujung pada kerusakan fungsi sel $\beta^{9}$.

Penderita diabetes mellitus akan terjadi stres oksidatif dan pembentukan radikal bebas peroksida. Radikal bebas peroksida akan menyerang substansi esensial sel $\beta$ pankreas dan mengawali kerusakan sel $\beta$ pankreas, sehingga terjadi penurunan sekresi insulin oleh sel $\beta$ pankreas. Kemampuan $\beta$-carotene sebagai antioksidan yang diduga mampu melindungi kerja pankreas dari radikal bebas dengan cara inaktivasi radikal bebas sehingga pankreas dapat bekerja secara optimal dalam menghasilkan insulin. ${ }^{10}$ Perlakuan dengan memberikan dosis bertingkat $\beta$-carotene (kelompok $\mathrm{X}_{2}, \mathrm{X}_{3}$ dan $\mathrm{X}_{4}$ ) dapat menurunkan kadar glukosa darah, masing-masing adalah 166,2 mg/dl, 206,98 mg/dl dan 261,25 mg/dl.

Penelitian Azza menunjukkan bahwa pemberian $\beta$ carotene dapat menurunkan glukosa darah dan dapat menjadi protektif pada kerusakan sel $\beta$ pankreas. $\beta$ Carotene diduga dapat memperbaiki kemampuan sel $\beta$ dalam mensintesis dan mensekresi insulin sehingga kadar glukosa darah dapat turun. Insulin akan menurunkan kadar glukosa darah dengan meningkatkan pemindahan glukosa kedalam jaringan adiposa dan otot dengan merekrut pengangkutan glukosa, ikatan insulin dan reseptornya membutuhkan GLUT4 untuk dapat masuk kedalam sel otot dan jaringan lemak serta uptake glukosa dengan efisien, sehingga dapat menurunkan kadar glukosa darah ${ }^{4}$.

Sharma et al menjelaskan bahwa $\beta$-carotene dapat menurunkan kadar glukosa darah dan dapat mencegah stres oksidatif. $\beta$-carotene dilaporkan dapat memproteksi sel $\beta$ pankreas dengan mengurangi stres oksidatif pada tikus yang diinduksi STZ. Antioksidan $\beta$-carotene dapat menangkap radikal bebas dan menghambat lipid peroksida serta memproteksi sel $\beta$ pankreas sehingga dapat meningkatkan sekresi insulin dan kadar glukosa darah dapat menurun ${ }^{6}$.

\section{Kadar MDA}

Malondildehida pada penderita diabetes mellitus dapat terjadi karena adanya hiperglikemia yang dapat menyebabkan radikal bebas terutama ROS dari berbagai jaringan yang berasal dari proses autooksidasi. Radikal bebas yang terbentuk dapat merusak membran sel menjadi lipid peroksida atau MDA.

Pengukuran konsentrasi MDA telah digunakan sebagai indikator kerusakan oksidatif pada lemak tak jenuh sekaligus sebagai indikator keberadaan radikal bebas. Hiperglikemia pada diabetes mellitus merangsang pelepasan superoksida $\left(. \mathrm{O}_{2}^{-}\right)$di tingkat mitokondria yang merupakan pemicu awal timbulnya stres oksidatif pada penderita diabetes mellitus dengan mengaktifkan nuclear factor kappa B cells $\left(\mathrm{NF}_{-\mathrm{K}} \mathrm{B}\right)$, p38 mitogen-actived protein kinase (MAPK), jalur poliol (sorbitol), heksosamine, protein kinase C (PKC) dan advanced glicosilation product (AGES) (Johansen et al, 2005). Radikal bebas yang timbul dapat merusak membran sel menjadi peroksida lipid atau MDA. Gangguan keseimbangan produksi ROS dan mekanisme pertahanan seluler mengakibatkan disfungi dan kerusakan sel atau stres oksidatif. ${ }^{11}$

Berdasarkan Tabel 2 dapat dilihat bahwa pada kelompok perlakuan $\mathrm{X}_{2}, \mathrm{X}_{3}$ dan $\mathrm{X}_{4}$ terjadi penurunan kadar MDA sebesar $0,75 \mathrm{nmol} / \mathrm{ml}, 0,85 \mathrm{nmol} / \mathrm{ml}$ dan $1,58 \mathrm{nmol} / \mathrm{ml}$. Penurunan kadar MDA paling banyak terdapat pada kelompok perlakuan yang diberi $\beta$ carotene dengan dosis $20 \mathrm{mg} / \mathrm{kg}$ BB. Hal ini sesuai dengan penelitian Thyagaraju (2008) melaporkan bahwa pemberian $\beta$-carotene $20 \mathrm{mg} / \mathrm{kg} \mathrm{BB}$ dapat menurunkan kadar ROS. Lipid peroksida yang rendah dapat mengindikasikan bahwa kerusakan yang disebabkan radikal bebas berkurang. Hal ini dikarenakan $\beta$-carotene dapat menangkap radikal bebas. 
$\beta$-carotene merupakan antioksidan eksogen yang mempunyai struktur molekul yang dapat memberikan elektronnya kepada molekul radikal bebas. Mekanisme kerja antioksidan $\beta$-carotene antaralain sebagai pemutus rantai yang dapat berinteraksi langsung dengan radikal bebas atau oksigen tunggal, mengubah jenis oksigen reaktif menjadi kurang toksik dan memperbaiki kerusakan yang timbul. ${ }^{12}$

Levy, et al menjelaskan penurunan bahwa $\beta$ carotene dapat meningkatkan status antioksidan pada penderita diabetes mellitus. $\beta$-carotene bersifat antioksidan dan dapat mengimbangi penumpukan radikal bebas pada keadaan hiperglikemia. Hiperglikemia dalam jangka panjang akan menyebabkan peningkatan produksi radikal. Peningkatan dan penumpukan radikal bebas dapat mengurangi status antioksidan endogen. $\beta$-Carotene mempunyai fungsi sebagai pemutus rantai radikal peroksida dengan cara mendonorkan ion hidrogen bagi radikal bebas, sehingga radikal bebas menjadi molekul yang lebih stabil. Pemberian $\beta$-Carotene sebagai antioksidan eksogen dapat meningkatkan status antioksidan dalam tubuh untuk menghambat produksi radikal bebas yang berlebihan, sehingga tidak terjadi komplikasi lebih lanjut ${ }^{13}$.

Hasil pada penelitian ini menunjukkan bahwa $\beta$ carotene mempunyai pengaruh terhadap penurunan kadar glukosa darah dan kadar MDA. Sumber $\beta$ carotene yang digunakan pada penelitian ini menggunakan sediaan bahan kimia sintesis standar penelitian yaitu dari $\beta$-carotene dari SIGMA Aldrich Singapore, C9570 type I synthetic $\geq 93 \%$ UV powder. Aplikasi dengan menggunakan bahan makanan yang mempunyai kandungan $\beta$-carotene untuk menurunkan kadar glukosa darah dan MDA. Bahan makanan yang mengandung $\beta$-carotene misalnya 100 gram wortel mengandung $8 \mathrm{mg} \beta$-carotene. Diketahui bahwa RDI $\beta$-carotene untuk dewasa adalah $6 \mathrm{mg} / \mathrm{hari}$ atau $10.000 \mathrm{IU} / \mathrm{hari}$, sehingga dengan mengkonsumsi wortel 100 gram $\beta$-carotene sudah dapat memenuhi RDI kebutuhan $\beta$-carotene. ${ }^{13,14}$

Berdasarkan hasil penelitian, dosis efisien $\beta$ carotene pada keadaan diabetik untuk dapat menurunkan kadar glukosa darah yaitu $10 \mathrm{mg} / \mathrm{kg}$ BB dan $20 \mathrm{mg} / \mathrm{kg}$ BB untuk menurunkan MDA. Dosis 10 $\mathrm{mg} / \mathrm{kg}$ BB jika dikonversikan ke dosis manusia yaitu $1,6 \mathrm{mg} / \mathrm{kg}$ BB. Aplikasi dosis $\beta$-carotene untuk manusia dengan $\mathrm{BB} 50 \mathrm{~kg}$ yaitu $80 \mathrm{mg} \beta$-carotene, setara dengan $\beta$-carotene pada 1000 gram wortel untuk dikonsumsi 2 hari sekali.

\section{SIMPULAN}

Ada penurunan kadar glukosa darah tikus jantan Sprague Dawley yang diinduksi STZ setelah pemberian dosis bertingkat $\beta$-carotene $1 \mathrm{mg} / \mathrm{kg} \mathrm{BB}$,
$10 \mathrm{mg} / \mathrm{kg}$ BB dan $20 \mathrm{mg} / \mathrm{kg}$ BB yang diberikan melalui sonde 2 hari sekali dalam 30 hari. Pemberian dosis $\beta$-carotene $10 \mathrm{mg} / \mathrm{kg} \quad \mathrm{BB}$ memberikan penurunan yang paling efektif dan efisien dibandingkan dengan dosis yang lain.

Ada penurunan kadar MDA tikus jantan Sprague Dawley yang diinduksi STZ setelah pemberian dosis bertingkat $\beta$-carotene $1 \mathrm{mg} / \mathrm{kg} \mathrm{BB}, 10 \mathrm{mg} / \mathrm{kg} \mathrm{BB}$ dan $20 \mathrm{mg} / \mathrm{kg}$ BB yang diberikan melalui sonde 2 hari sekali dalam 30 hari. Pemberian dosis $\beta$-carotene 20 $\mathrm{mg} / \mathrm{kg}$ BB memberikan penurunan yang paling efektif dan efisien dibandingkan dengan dosis yang lain.

\section{SARAN}

Penelitian selanjutnya perlu diteliti kandungan antioksidan dalam pakan yang mungkin juga berpengaruh terhadap kadar glukosa darah dan MDA pada diabetes mellitus.

\section{DAFTAR PUSTAKA}

1. PERKENI. Konsensus Pengelolaan dan Pencegahan Diabetes Mellitus Tipe 2 di Indonesia. Jakarta. 2001.

2. Takashi H, Tran PO, LeRoy E, Harmon JS, Tanaka Y and Robetson RP. d-Glyceraldehyde Causes Production of Intracellular Peroxcide in Prancreatic Islets, Oxidative Stress, and Defective-cell Functions via Non-Mitocondrial Pathways. J Biol Chem. 2004;279:16 -23.

3. Hanachi P, Moghadam R, Latiffah AL. Investigation of Lipid Profiles and Lipid Peroxidation in Patient with Type-2 Diabetes Rats. Europan J of Sci Res. 2009;28(1):6-13

4. Azza AT. Histological and Electron Microscopic Studies of the Effect of $\beta$-Carotene on the Pancreas of Streptozotocin (STZ) Induced Diabetic Rats. Pakistan Journal of Biological Sciences. 2009;12(4): 301-314.

5. Furusho T, Kataoka T, Yasuhara M, Wada, S Innami. Administration of Beta-Carotene Suppreses Lipid Peroxidation In Tissues and Improves the Glucose Tolerance Ability of Streptozotocin-Induced Diabetic Rats. Int $\mathbf{J}$ Vitam. 2002;72:71-76

6. Sharma M, Katyal T, Grewal G, Behera D, Budhiraja RD. Effect of Antioxidants Such as $\beta$ Carotene, Vitamin $\mathrm{C}$ and Vitamin $\mathrm{E}$ on Oxidative Stress, Thermal Hyperalgesia and Cold Allodyna in Streptozotocin Induced Diabetic Rats. The International Jurnal of Pharmacology. 2009;15312976.

7. Thyagaraju BM, Shrilatha B, Muralidhara. Oral Suplementasi of $\beta$-Carotene Significantly Ameliorates Testicular Oxidative Stress in the 
Streptozotocin-Diabetic Rat. International J. Fertility and Sterility. 2008; 2(2): 74-81

8. Szkudelski, T. The Mechanism of Aloksan and Streptozotocin Action in $\beta$ Cells of The Rats Pancreas. Physiol Res. 2001; 50: 536-546

9. Matthew, J.S. Molecular Understanding of Hyperglycemia's Adverse Effects for Diabetic Complications. JAMA. 2002; 288(20)

10. Schteingrat DE. Pankreas: Metabolisme Glukosa dan Diabetes Melitus. Dalam Price SA, Wilson LM. Patofisiologi: Konsep klinis proses-proses penyakit. Edisi 6 Volume 2. Jakarta: ECG. 2003.

11. Tandon V, Groupta BM, Tandon R. Free Radicals/Reactive Oxygen Species. JKPractitioner. 2005; 12(3):143-8

12. Stahl W, Sies, H. Antioxidant Activity of Carotenoids. Molecular Asfects of Medicine. 2003; 24:345-351.

13. Levy Y, Zaltzberg H, Ben-Amotz A, Kanter Y, Michael Aviram. B-Carotene Effects Antioxidant Status in Non-Insulin-dependent Diabetes Mellitus. Elsevier Science Ireland. 1999; 6: 157161

14. United States Department of Agriculture. National Nutrient for Standard Reference Release 21. http://www.ars.usda.gov/Services

/docs.htm?docid=17477. Diambil: 1 maret 2013 